\title{
Correlation between Emotional Intelligence and Cognitive Symptoms in Schizophrenia
}

\author{
Amit Kumar'; Masroor Jahan²; Amool R. Singh ${ }^{3}$
}

\begin{abstract}
:
Sehizophrenia is characterized by cognitive dysfunction and disturbed inter-personal relationship. Emotional intelligence operates across both the cognitive and emotional systems. The present study examined correlation between cognitive symptoms (i.e. attention/concentration, memory. visual functioning, language and executive functioning) and emotional intelligence (i.e. intra-personal awareness, inter-personal awareness, intra-personal management and inter-personal management) in patients with schizophrenia. Thirty five patients with schizophrenia diagnosed according to the ICD-10 $D C R$ were individually assessed on Cognitive Symptoms Checklist and Mangal Emotional Intelligence Inventory to examine the correlation between cognitive symptoms and emotional intelligence. Results revealed that activity of daily ining: money management was significantly correlated with all the areas of emotional intelligence. Internal distractors: emotional, and simultaneous attention were significantly correlated with most of the areas of emotional intelligence. Figure/ground, hearing and processing speed were significantly assoclated with inter-persanal management. Mental flexibility, planning and sequencing were significantly associated with inter-personal awareness.
\end{abstract}

Key Words: cognitive symptoms, emotional intelligence, schizophrenia.

\section{INTRODUCTION}

Scientific findings on emotional intelligence support the notion that emotions are functional when the information they provide is attended to, interpreted accurately, integrated into thinking and behavior, and managed effectively. Acwording to emotional intelligence theory, the cognitive, physiological, and behavioral changes that accompany emotional responses are adaptive - these changes prepare us to respond to the event that caused the emotion to occur.' The theory also asserts that emotions serve important social functions, conveying information about other people's thoughts, intentions, and behavior. ${ }^{2}$ Indeed, the ability to integrate emotional information into cognitive activities is essential to effective functioning across the life cotirse, ${ }^{3}$

There have been relatively a few researches on the relationship between emotional abilities and performance on cognitive task5. Theoretical work suggests that exploration of the influence adaptive emotions may have on task performance would enhance our understanding of both task performance and emotion. Singer' and Izards pointed out that emotions are an important component of the tapestry of consciousness and cognitive processes. Both Piaget ${ }^{*}$ and Damasio? argued that emotions may fuel or energize cognitive functioning and learning.
Growing evidence suggests that social cognitive variables such as emotional intelligence mediate rela-tions between neurocognition and social functioning in schizophrenia. ${ }^{3.9}$. In 11 Eack et al ${ }^{12}$ used the MayerSalovey-Caruso Emotional Intelligence Test (MSCEIT) to examine changes in the emotional intelli-gence of persons with sehizophrenia resulting from Cognitive Enhancement Therapy. A series of analyses of covariance showed highly significant and large effects favoring Cognitive Enhancement Therapy for improving emotional intelligence, with the most pronounced improvements occurring in patients' ability to understand and manage their own and others' emotions. These findings lend preliminary support to the previously documented benefits of Cognitive Bnhancement Therapy on social cognition in schizophrenia, and suggest that such benefits can be extended to patients in the early course of the illness.

Aguirre et al. ${ }^{13}$ examined emotional intelligence in persons with schizotypy. Undergraduates identified as high or low in schizotypy based on their responses to the Schizotypal Personality Questionnaire - Brief Version ${ }^{14}$ were administered the Mayer-Salovey-Canuso Emotional Intelligence Test's. The second aim of their study was to examine relations between the emotional intelligence of persons with high schizotypy and aspects of their social 
and neurocognitive functioning. The Social Adjustment Scale - Self Report ${ }^{t b}$ was used to assess three aspects of social functioning: academic functioning, relations with peers and relations with family. Executive functioning and verbal episodic (secondary) memory were selected as neurocognitive constructs because they are often impaired in schizophrenia spectrum disorders. Assessing with Mayer-Salovey-Caruso Emotional intelligence Test, person high in schizotypy were im-puired in overall emotional intelligence and two aspects of emotional intelligence, namely, the ability to perceive emo-tions and the ability to manage emotions. The finding of impaired emotional intelligence in schizo-types is consistent with the prior studies of social cog-nition in schizotypy that have identified impairments in emotion perception and theory of mind. $17, i x, 1 s$

Emotional intelligence and its elements were asso-ciated with neurocognition and social functioning in persons with high schizotypy. Overall emotional intel-ligence was associated with aspects of verbal episodic (secondary) memory in the persons with high schizo-typy, The understanding emotions and managing emo-tion branches of emotional intelligence were associated with indicators of verbal episodic (socondary) memory and executive functioning in the persons with high schizotypy. ${ }^{13}$

Neurocognition affects social cognition and that poorer social cognition leads to social diseomfort on the job, which in turn keads to poorer rehabilitation outcomes. ${ }^{30}$

Emotional intelligence was found to be associated with working memory capacity, followed by verbal memory, sustained attention/vigilance and negativity. These factors strongly predicted poorer social functioning in first episode schizophrenia, along with poorer quality of life in psychological, social, and health satisfaction facets. ${ }^{21}$

Hence, this study is an effort for better understanding of association between cognitive symptoms and emotional intelligence of the patients with schizophrenia so that, specific cognitive rehabilitation strategies can be made which may help them to improve their emotional intelligence. This will surely help them to adjust in their society in a better way.

\section{METHODOLOGY}

This is a cross sectional study designed to assess correlation between cognitive symptoms and emotional intelligence of schizophrenic patients.

\section{Sample:}

A sample consisting of thirty five schizophrenic patients was taken using purposive sampling technique. Most of the patients were in the age range of 20-35 years $(60 \%)$. Most of the patients were educated up to matric $(60 \%)$. All patients were male and most of them were married $(60 \%)$ and unemployed $(54 \%)$. Most of the patients were Hindus (77\%), from joint families $(60 \%)$ and belonging to lower socio-economic status $(63 \%)$ hailing from rural areas (71\%) of Jharkhand and Bihar. Schizophrenic patients with any other neurological disorder'major physical illness were excloded. All subjects were cooperative and gave consent for the study.

\section{Tools:}

Socio-demographic Data Sheet: To collect information regarding socio-demographic claracteristics and other related information of the sample a socio-demographic dattr sheet was developed for the present study.

Brief Psychiatric Rating Seale (BPRS): BPRS is 18items well established scale developed by Overall \& Gorhum (1962) $)^{22}$ measuring positive symptoms, general psychopathology and affective symptoms.

Cognitive Symptom Checklist: Cognitive Symptom Checklist is originally developed by Christine $\mathrm{O}^{\prime} \mathrm{Hars}$ et al. $(1993)^{23}$. In this study Hindi adaptation (Jahian et al., $2010)^{24}$ of cognitive symptoms checklist was used. It is an important clinical tool, to identify the problems in daily living skills under the heading of attention/concentration, memory, visual functioning, language and execution. This cognitive domains of attention and concentration was further subdivided into the areas of internal distracter (physical, emotional), external distracter (visual, auditory and environmental), sustained attention, divided attention and simultaneous attention. The domain of memory was further subdivided into activities of daily functioning (medication, nutrition/ food preparation sequence, safety, routine, money management, spatial relationship) time and receptive language. The domain of visual process was further divided into vision, visual field/neglect, scanning discrimination, figure-background, mental imagery and organization. Language was further subdivided into the following headings: hearing, speaking, receptive language (auditory), receptive language (written), expressive language (speaking) and expressive language (writing). Executive functioning was divided into following sub divisions-processing speed/reaction time, initiation/followthrough, self correction, mental flexibility, planning, organization and reasoning. The Cognitive Symptom 
Checklist provides a frame work from which clinicians can gather additional information about the nature of specific problems to target to treatment and it prioritizing problems for treatment. Using Cognitive Symptom Checklist, the clinicians can provide both fine tuning of the specific problems areas to be addressed and appropriate situations for the practices of strategies.

Mangal Emotional Intelligence Inventory (MEII): It is 100 items inventory developed by Mangal \& Mangal $(2004)^{25}$ assesses four areas or aspects of emotional intelligence, namely, intra-personal awareness (knowing about one's own emotions), inter-personal awareness (knowing about other's emotions), intra-personal munagement (managing one's own emotions), and interpersonal management (managing other's emotions). Each area consists of 25 questions to be answered as YES or NO.

\section{Procedure:}

Participants were selected according to inclusion and exclusion criteria. Severity of psychopathology was assessed by Brief Psychiatric Rating Scale. Socio demographic information was collected using the Socio demographic Data Sheet. Information was gathered from reliable sources. Cognitive Symptom Checklist and Mangal Emotional Intelligence Inventory were administered to all participants.

\section{Statistical analysis:}

Data obtained was analyzed with respect to the objectives of the study. Frequency, percentage and correlation were applied for the analysis of the data. Statistical Packages for Social Sciences (SPSS) was used for analysis.

\section{RESULTS}

Correlation was calculated between variables of cognitive symptoms and emotional intelligence. Negative comelation was found for most of the variables. Higher score on emotional intelligence suggests better emotional intelligence, whereas, higher score on cognitive symptoms suggests poor performance. Hence, negative correlation suggests that better emotional intelligence is related to better cognitive functioning.

Table 1 shows that impairment in internal distracters: emotional and simultaneous attention, were significantly negatively correlated with inter-personal awareness, interpersonal management and total emotional intelligence. It suggests that the higher impairment in internal distracters: emotional and simultaneous attention, were associated with poor inter-personal awareness, inter-personal management and total emotional intelligence. Impaiment in external distractors: auditory was associated with poor interpersonal management. Impairment in divided attention was significantly negatively correlated with inter-personal awareness.

Table 2 shows that difficulty in activity of daily living: money management was significantly correlated with all the four areas of emotional intelligence i.e. intra-personal awareness, inter-personal awareness, intra-personal management and inter-personal management. Difficulty in activity of daily living: medication was significantly correlated with poor inter-personal awareness and total emotional intelligence, activity of daily living: nutrition was significantly correlated with poor intra-personal awareness and total emotional intelligence, activity of daily living: safety was significantly correlated with poor inter-personal management and total emotional intelligence, activity of daily living: routine was associnted with poor intra-personal management and total emotional intelligence. Deficit in expressive language was associated with poor intrapersonal management. Difficulty in other sections of memory was not significantly correlated with any of the area of emotional intelligence.

Table 3 shows that difficulty in figure/ground was associated with poor inter-personal management, but no other section of visual process was significantly correlated with any area of the emotional intelligence.

Table 4 shows that hearing was associated with interpersonal management, but no other section of language significantly correlated with any area of emotional intelligence.

Table 5 shows that impairment in processing speed was associated with poor inter-personal management. Deficit in mental flexibility, planning and sequencing were associated with poor interpersonal awareness. Problem in initiation, problem solving, organization and reasoning were not significantly correlated with any of the area of emotional intelligence.

\section{DISCUSSION}

The result suggests that there is significant negative correlation between cognitive symptoms and emotional intelligence in patients with schizophrenia. Emotional intelligence has been suggested to be an important mediating variable in the relationship between neurocognition and functionaloutcome. There is considerable inconsistency in findings regarding the 
relationship between specific cognitive deficits and social impairment in patients with schizophrenia. This. inconsistency may relate to variability across studies in how social functioning is measured and preliminary evidence suggests that different indices of social functioning (e.g., laboratory test, community assessment) may have different cognitive correlates, ${ }^{36}$

Result shows that attention was significantly correlated with emotional intelligence. Mainly emotional distractors and simultaneous attention were significantly negatively correlated with inter-personal awareness, interpersonal management and total emotional intelligence. Attention plays a critical role in day-to-day functioning. For instance, attention is important while conversing with others successfully. Hence, association between attention and emotional intelligence is important. It can be helpful to improve the social and occupational functioning of individuals with schizophrenia and thus enhance their quality of life.

Memory efficiency has been shown to play a crucial role in daily living and social outcome in patients with schizophrenia. ${ }^{21}$ It is therefore particularly important to determine the factors that are involved in the memory. impaiment consistently observed in this population, in order to develop more targeted and effective treatment. In sections of memory difficulty in remembering personal things was significantly correlated with intra-personal management, inter-personal management and total emotional intelligence. Difficulty in remembering routine of daily activity and expressive language were significantly correlated with intra-personal management. In a previous study overall emotional inteliigence was associated with verbal episodic (secondary) memory, but not executive functioning, in persons with high schizotypy. ${ }^{17}$

In the domain of visual process difficulty in figuref ground perception was significantly negatively correlated with inter-personal management. Visual processing may contribute to deficits on neuropsychological tests of visual cognition, and may also reflect cross-modal disturbances of working memory function. 24

In the domain of language difficulty in hearing was significantly correlated with inter-personal management. Negative cmotion impairs language production, at least in part by increasing physiological arousal. ${ }^{20} \mathrm{But}$ in previous studies Bommer et al. ${ }^{36}$ concluded that patients with pure delusional disorder have difficulties in metaphorical speech omprehension fut their basic social cognitive abilities were preserved. However, no such study was found òn schizophrenic patients.
In executive functions processing speed and self correction were significantly negatively correlared with inter-personal management Mental flexibility, planning and sequencing were significantly correlated with inter-personal awareness. These findings are supported by earlier studies reporting that executive functioning is associated with social cognitive deficits. ${ }^{30}$ In the other study it was found that emotional intelligence was not associated with executive functioning with person with high schizotypy."

Initial research by Schutte et al. ${ }^{31}$ and Schutte and Malouff found a link between emotional intelligence and performance in the cognitive domain. Emotional intelligence predicted student's performance independently of cognitive ability.

Overall, findings of the present study suggest that cognitive symptoms are correlated with emotional intelligence in schizophrenic patients. However, there are few limitations of this study. Only male participants were included and effect of medication could not be controlled. Further research is needed on drug eontrolled patients of both genders controlling severity of psychopathology. Longitudinal study may help to shed more light on the progress and stability of cognitive symptoms. Such investigations could yield important insights regarding the dimensionality of emotional intelligence deficits in schizophrenia and their correlation with cognitive symptoms.

\section{References}

1. Lazarus RS. Emotion and Adaptation. New York: Oxford University Press; 1991.

2. Keltner D \& Haidt J. Social functions of emotions. In: Mayne TJ \& Bonanno GA (eds). Emotions: Current Issues and Future Directions. New York: Guilford Press; 2001: 192-213.

3. Damasio AR. Descartes' Error: Emotion, Reason, and the Human Brain. New York: Grosset/Putnam: 1994.

4. Singer UL. Experimental Studies of Daydreaming and the Stream of Thought. In: Pope KS and Singer IL (eds). The Stream of Consciousness, Plenum, New York; 1978.

5. Izsrd CL. The Psychology of Emotions, Plenum, New York; 1991.

6. Piaget J. Intelligence and Affectivity. Annual Reviews, PaloAlto; 1981. 
7. Damasio A. The Feeling of What Happens: Body and Emotions in the Making of Consciousness. Hartcourt Brace, New York; 1999.

8. Addington J, Saeedi H \& Addington D. Facial affect recognition: a mediator between cognitive and social functioning in psychosis? Schizophrenia Research 2006; 85:142-150.

9. Brekke JS, Kay KS \& Green MF. Biosocial pathway to functional outcome in schizophrenia. Schizophrenia Research 2005; 80:213-225.

10. Sergi MJ, Rassovsky Y, Nuechterlein KH \& Green MF. Social perception as a mediator of the influence of early visual processing on functional status in schizophrenia. American Journal of Psychiatry 2006; 163:448-454.

11. Vauth R, Rusch N, Wirtz M \& Corrigan PW. Does social cognitive influence the relation between neurocognitive defieits and vocational functioning in schizophrenia? Psychiatry Research 2004; 128:155165.

12. Eack SM, Hogarty GE, Greenwald DP et al. Cognitive enhancement therapy improves emotional intelligence in early course schizophrenia: preliminary effects. Schizophrenia Rescarch 2007; 89:308-311.

13. Aguirre F, Sergi MJ \& Levy CA. Emotional intelligence and social functioning in persons with schizotypy. Schizophrenia Research 2008; 104:255. 264.

14. Raine A \& Benishay D. The SPQ-B: a brief screening instrument for schizotypal personality disorder. Joumal of Personality Disorder 1995; 9:346-355.

15. Mayer JD, Salovey P \& Caruso DR. Mayer-SaloveyCaruso Emotional Intelligence Test (MSCEIT): User's Manual. Multi-health Systems, Inc., Toronto, Canada; 2002 .

16. Weissman MM, Prusoff BA, Thompson Det al. Social adjustment by self-report in a community sample and in psychiatric outpatients. Journal of Nervous and Mental Disease 1978; 166:317-326.

17. Langdon R \& Coltheart M. Recognition of metaphor and irony in young adults; the impact of schizotypal personality traits. Psychiatry Research 2004; $125: 9$ 20 .
18. Pickup GJ. Theory of mind and its relation to schizotypy, Cognitive Neuropsychiatry 2006; 11:177. 192.

19. Platek SM, Fonteyn LCM, Myers TE et al. Functional near infrared spectroscopy reveals differences in selfother processing as a function of schizotypal personality traits. Schizophrenia Research 2005; $73: 125-127$.

20. Bell M, Tsang HWH, Greig TC \& Bryson GJ. Neurocognition, social cognition, perceived social discomfort, and vocational outcomes in Schizophrenia. Schizophrenia Bulletin 2008; 35;738-747.

21. Williams LM, Whitford TJ, Flynn Get al. General and social cognition in first episode schizophrenia: identification of separable factors and prediction of functional outcome using the IntegNeuro test battery. Schizophrenia Research 2008; 99:182-191.

22. Overall JE \& Gorham DR. The Brief Psychiatric Rating Scale. Psychological Rehabilitation 1962; $10: 799.812$.

23. O'Hara $C$, Harrell M, Bellingrath E \& Lisicia K. Cognitive symptom checklist: Clinician's Guide. Psychological Assessment Resources, Ine, Florida; 1993.

24. Jahan M, Singh AR, Sengar KS \& Prakash J. Hindi adaptation of Cognitive Symptoms Checklist, Indian Journal of Psychometry and Education 2010; 41(2): $168-176$

25. Mangal SK \& Mangal S. Manual for Mangal Emotional Intelligence Inventory. National Psychological Corporation, Agra; 2004.

26. Cohen A, Forbes C, Mann M \& Blanchard J. Specific cognitive deficits and differential domains of social functioning impaiment in schizophrenia. Schizophrenia Research 2006; 81: 227-238.

27. Green MF. What are the functional consequences of neurocognitive deficits in schizophrenia? American Journal of Psychiatry 1996; 153:321-330.

28. Brenner CA, Lysaker P, Wilt MA \& O'Donnell BF. Visual processing and neuropsychological function in schizoplurenia and schizoaffective disorder. Psychiatry Research 2002; 111(2): 125-136.

29. Burbridge JA, Larsen RJ \& Barch DM. Affective Reactivity in Language: The Role of 
Psychophysiological Arousal. Emotion 2005; 5(2): 145 153.

30. Bormmer 1 \& Brüne M. Social cognition in "pure" delusional disorder. Cognitive Neuropsychiatry 2006; II:493-503.

31. Schutte NS, Malouff JM, Hall LE et al. Development and Validation of a Measure of Emotional Intelligence. Personality and Individual Differences 1998;25:167177.

32. Schutte NS \& Malouff JM. Measuring Emotional Intelligence and Related Constructs, Edwin Mellen Press, Lewiston, New York; 1999.

Table 1: Showing the correlation between attention/ concentration and emotional intelligence

\begin{tabular}{|c|c|c|c|c|c|}
\hline & $\begin{array}{l}\text { ltiro } \\
\text { personal } \\
\text { Anavaitse }\end{array}$ & $\begin{array}{l}\text { iner. } \\
\text { personal } \\
\text { Awarovest }\end{array}$ & $\begin{array}{l}\text { Intra: } \\
\text { gersenal } \\
\text { Nensgemine }\end{array}$ & $\begin{array}{l}\text { bier- } \\
\text { partord } \\
\text { Hazeganant }\end{array}$ & Total \\
\hline $\begin{array}{l}\text { inserna } \\
\text { distracios } \\
\text { physical }\end{array}$ & .103 & .055 & .210 & .236 & -138 \\
\hline $\begin{array}{l}\text { Intemal } \\
\text { Ifstractors: } \\
\text { Enctiona: }\end{array}$ & -125 & $-A C C^{\prime}$ & .226 & $-3 B T$ & -394 \\
\hline $\begin{array}{l}\text { Extemal } \\
\text { dstrectors: } \\
\text { Visual }\end{array}$ & 309 & -000 & 303 & -146 & 206 \\
\hline $\begin{array}{l}\text { Exlernal } \\
\text { distractors: } \\
\text { Auditory }\end{array}$ & 143 & $\leqslant 147$ &, 128 & -348 & .040 \\
\hline $\begin{array}{l}\text { External } \\
\text { dstractors: } \\
\text { exrivonencrial }\end{array}$ & 0937 & 012 & 223 & -051 & $.10 t$ \\
\hline $\begin{array}{l}\text { Sustahed } \\
\text { corcertidion }\end{array}$ & .009 & .212 & -162 & .236 & -213 \\
\hline $\begin{array}{l}\text { Divided } \\
\text { attention }\end{array}$ & -062 & $-344^{t}$ & -051 & .138 & -199 \\
\hline $\begin{array}{l}\text { Simulaneous } \\
\text { dientoi }\end{array}$ & -234 & $-616^{2}$ & -000 & $3 \pi T$ & $-443^{2}$ \\
\hline
\end{tabular}

"significant at 0.05 level," "significant at 0.01 levef.
Table 2: Showing the correlation between memory and emotional intelligence

\begin{tabular}{|c|c|c|c|c|c|}
\hline & $\begin{array}{l}\text { intrat } \\
\text { persenal } \\
\text { Pwareness }\end{array}$ & $\begin{array}{l}\text { itter- } \\
\text { persanal } \\
\text { Aerarennat }\end{array}$ & $\begin{array}{l}\text { intra } \\
\text { persanal } \\
\text { Nanagimant }\end{array}$ & $\begin{array}{l}\text { Iner- } \\
\text { perszual } \\
\text { Unazenent }\end{array}$ & Tots \\
\hline $\begin{array}{l}\text { Activly of daly } \\
\text { furgnedication }\end{array}$ & 1 & $483^{\circ}$ & 216 & 229 & $705^{\circ}$ \\
\hline $\begin{array}{l}\text { activily of daily } \\
\text { iving nutrition }\end{array}$ & $483^{\circ}$ & 1 & 180 & 262 & $580^{\circ}$ \\
\hline $\begin{array}{l}\text { activity of dally } \\
\text { living salety }\end{array}$ & .216 & 580 & 1 & $.450^{\circ}$ & .713 \\
\hline $\begin{array}{l}\text { sctiviny of daily } \\
\text { living: roufine }\end{array}$ & 229 & 262 & $450^{\circ}$ & 7 & $60 \%$ \\
\hline $\begin{array}{l}\text { activity of daily } \\
\text { living: money } \\
\text { maragenent }\end{array}$ & 705 & $.860^{\circ}$ & .713 & 867 & 1 \\
\hline $\begin{array}{l}\text { actinity of daily } \\
\text { lving: spatias } \\
\text { retalionship }\end{array}$ & 193 & .214 & 053 & $.66 ?$ & 012 \\
\hline Tim & 271 & -177 & .183 & -005 & 125 \\
\hline $\begin{array}{l}\text { recspofue } \\
\text { langurge }\end{array}$ & 243 & -112 & 017 & -133 & 045 \\
\hline $\begin{array}{l}\text { expressive } \\
\text { language }\end{array}$ & .216 & -229 & 339 & $D 12$ & 000 \\
\hline Personal & $0 Q 7$ & $-10 ?$ & -066 & 141 & -116 \\
\hline
\end{tabular}

"sigificant at o 05 leved, "significant at 0.01 leved

Table 3: Showing the correlation between visual processing and emotional intelligence

\begin{tabular}{|c|c|c|c|c|c|}
\hline & $\begin{array}{l}\text { intrs- } \\
\text { personal } \\
\text { Marenenst }\end{array}$ & $\begin{array}{l}\text { letes. } \\
\text { personal } \\
\text { Amartenes }\end{array}$ & $\begin{array}{l}\text { Ftra } \\
\text { personal } \\
\text { Ninageneri }\end{array}$ & $\begin{array}{l}\text { Ther: } \\
\text { gersongi } \\
\text { Vevisjenest }\end{array}$ & Tatal: \\
\hline Vision & .120 & $-05 \pi$ & -149 & -116 & -072 \\
\hline Visual fedd & .032 &., 024 & -.147 & .158 & -.707 \\
\hline Scanning & 170 & .092 & .199 & $-\infty 001$ & D77. \\
\hline Degorrination & 162 & .068 & 111 & $-0: 4$ & 929 \\
\hline Figrabound & De8 & -078 & - - Dan & $-464^{2}$ & $-14 i$ \\
\hline Mentalimagory & 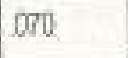 & -156 & 0.17 & -051 & $-0,031$ \\
\hline $\begin{array}{l}\text { Spatal } \\
\text { relatonshp }\end{array}$ & .015 & $: 117$ & 019 & -111 & .089 \\
\hline Organizatont & -120 & .034 & $0 \pi 7$ & -188 & -0050 \\
\hline
\end{tabular}

* significant at 0.05 level, ** significant at 0.01 level 
Table 4: Showing the correlation between language and emotioaal intelligence

\begin{tabular}{|c|c|c|c|c|c|}
\hline & $\begin{array}{l}\text { letra } \\
\text { parsond } \\
\text { Awsreacss }\end{array}$ & $\begin{array}{l}\text { latur- } \\
\text { Versonal } \\
\text { Awereniss }\end{array}$ & 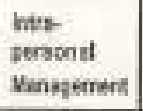 & $\begin{array}{l}\text { Inter: } \\
\text { pereans } \\
\text { Mnagenent }\end{array}$ & Tetai \\
\hline Heering & 248 & -0024 & 270 & $-355^{\circ}$ & .140 \\
\hline Sperking & 232 & 212 & $=912$ & -227 & 086 \\
\hline $\begin{array}{l}\text { receptive } \\
\text { langiage; } \\
\text { auditary }\end{array}$ & .180 & .010 &,- 065 & -267 & -.041 \\
\hline $\begin{array}{l}\text { receptive } \\
\text { iengusge: } \\
\text { wriken }\end{array}$ & .022 & -117 & .066 & -244 & -0.077 \\
\hline $\begin{array}{l}\text { expressive } \\
\text { languege; } \\
\text { speaking }\end{array}$ & -063 & -270 & .047 & -110 & -161 \\
\hline $\begin{array}{l}\text { expressive } \\
\text { language: } \\
\text { witing }\end{array}$ & 234 & -053 & 154 & 5158 & .950 \\
\hline
\end{tabular}

* significant at 0.05 level, ** significant at 0.01 level

Table 5: Showing the correlation between executive functioning and emotional intelligence

\begin{tabular}{|c|c|c|c|c|c|}
\hline & $\begin{array}{l}\text { intre } \\
\text { pasabasi } \\
\text { Awarenes }\end{array}$ & $\begin{array}{l}\text { mer- } \\
\text { persenal } \\
\text { Awyreness }\end{array}$ & $\begin{array}{l}\text { Ifro } \\
\text { personal } \\
\text { Mansegencet }\end{array}$ & $\begin{array}{l}\text { hier- } \\
\text { pertanal } \\
\text { Astagerent }\end{array}$ & Tabal \\
\hline $\begin{array}{l}\text { Processing } \\
\text { speed }\end{array}$ & 201 & $=132$ & .063 & -3000 & -106 \\
\hline intianon & 082. & -152 & 0.040 & -221 & -099 \\
\hline selfornodion & 252 & 5185 & 213 & 322 & 227 \\
\hline $\begin{array}{l}\text { Marital } \\
\text { fexibiaty }\end{array}$ & .205 & .426 & 006 & -228 & -251 \\
\hline Planning & 174 & $-430^{\circ}$ & .032 &, 150 & -236 \\
\hline Sequending & -064 & -355 & -143 & -168 & -248 \\
\hline $\begin{array}{l}\text { problam } \\
\text { solving }\end{array}$ & $2028=$ & $264 \cdot 7$ & 240 & -445 & tonas \\
\hline Orgarization & .093 & 236 & 232 & -029 & 052 \\
\hline Ressoning & $05 t$ & -263 & 221 & .078 & 1684 \\
\hline
\end{tabular}

* significant at 0.05 level, ** significant at 0.01 level

\section{Authors}

1. Ph.D. Scholar, Dept. of Clinical Psychology, RINPAS, Kanke, Ranchi-6, Jharkhand, o-mail: amkumar510@yahoo,in

2. Additional Professor of Clinical Psychology, RINPAS, Kanke, Ranchi-6, Jharkhand, email: mastoorjahan@hotmail.com. masrooriaban@gmail.com

3. Director, RINPAS, Professor and Head, Department of Clinical Psychology, RINPAS, Ranchi, Jharkhand, e-mail: sisamool@yahoo.com, singh_amool@rediffmail.com

Address for correspondence:

Prof.Amool R. Singh,

Director, RINPAS

Professor and Head, Department of Clinical Psychology, Ranchi Institute of Neuro- Psychistry and Allied Sciences (RINPAS) Ranchi 834006, Jharkhand, e-mail: sisamool@yahoo.com. singh_amool@rediffmail.com

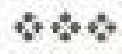

